\title{
UTRINKI S KONFERENCE "SISTEMI IN TRENDI V IZOBRAŽEVANJU ODRASLIH«
}

zobraževanje odraslih ne poteka $v$ praznem prostoru. Tako kot druge prakse in vede drži zrcalo družbenemu, ekonomskemu ter političnemu položaju in razvoju družbe. V njem se zrcalijo družbena razmerja in odsevajo duhovne predstave, pa tudi kulturni dosežki in vrednote posameznega družbenega okolja. Še več, sistem je temelj, ki spodbuja in omejuje razvoj izobraževanja odraslih.

Vprašanja sistema in razvoja izobraževanja odraslih v različnih državah smo obravnavali na konferenci Sistemi in trendi v izobraževanju odraslih. Konferenca je potekala v Balatonalmadi na Madžarskem v organizaciji madžarskega inštituta za kulturo in Lazsla Harangija, človeka z razvitim smislom za animacijo ljudi.

Konferenca je bila konzultativne narave, tako da smo bili vsi povabljeni ves čas na voljo za svetovanje madžarskim kolegom. Pregled izobraževalnih sistemov v Italiji, na Irskem, v Švici, Španiji in Sloveniji je bil podlaga za primerjavo in ugotavljanje nekaterih zakonitosti, ki obvladujejo današnji razvoj in izobraževanje odraslih. Izkazalo se je, da države, ki ne ugotovijo dovolj hitro, da prehajajo iz industrijskega družbenega koncepta $\mathrm{v}$ koncept informacijske družbe, in ki svoj razvoj ter izobraževanje odraslih vodijo po starih metodah, zamujajo. Nekako spominjajo na starajočo se osebo, ki se ne more sprijazniti s tem, da je že $v$ novem življenjskem obdobju, in skuša na vse pretege zadržati mladost. $\mathrm{V}$ teh prizadevanjih zamudi razvojne priložnosti, ki bi se ji sicer pokazale, če bi jih zmogla le sprejeti, in tako da na koncu ostane praznih rok, na zgrešeni poti razvoja.

\section{SISTEM IZOBRAŽEVANIA ODRASLIH V ITALIJI}

Pomen izobraževanja odraslih $\mathrm{v}$ očeh posamezne družbe kaže že to, v katero ministrstvo, in če sploh v katero, spada izobraževanje odraslih. V Italiji je denimo za izobraževanje odraslih odgovorno ministrstvo za delo, ki ima svoj oddelek za izobraževanje odraslih. Ni nenavadno, da so v tej državi izobraževanje odraslih doslej videli predvsem v povezavi z zaposlitvijo. Tudi podatki o splošni izobraženosti Italijanov niso spodbudni. V letu 1988 je bilo v tej državi tri milijone aktivnega prebivalstva, 23 odstotkov tega prebivalstva pa je končalo zgolj osnovno šolo. Še več, Italija je imela takrat 8 odstotkov nepismenih prebivalcev in $\mathrm{v}$ zadnjem času se zaradi brezposelnosti ter drugih sprememb

V Italiji so zaposle-
ni upravičeni do
150 plačanih ur
izobraževanja med
delovnim casom.
znova pojavlja problem nepismenosti. Mnogi mladi ne pišejo, ne berejo ali pa berejo zelo malo, zato so funkcionalno nepismeni. Televizija je sicer pripomogla $\mathrm{k}$ temu, da se je pojmovni svet odraslih razširil, in temu je sledilo tudi boljše znanje ustnega jezika. Ni pa mogla pripomoči $\mathrm{k}$ temu, da bi ljudje brali in pisali.

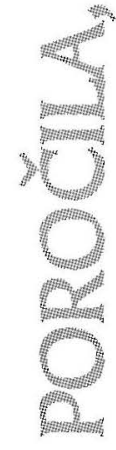

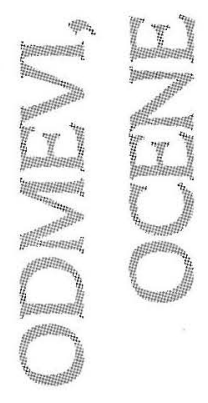


Število starejših prebivalcev se $\mathrm{v}$ tej državi povečuje in pričakujejo, da jih bo leta 2040 že 41 odstotkov Tudi staranje prebivalstva je pripomoglo k razširjenju izobraževanja odraslih in $\mathrm{v}$ šestdesetih letih so ga začeli obravnavati kot sistem. Pred tem so v Italiji poznali le občasne med seboj nepovezane izobraževalne oblike, kot so večerne šole za delavce ali pa bralni krožki itd. Oblikovanje sistema izobraževanja odraslih v šestdesetih letih kaže na takratno družbeno prepoznavanje problemov in spoznanje, da jih je mogoče reševati z izobraževanjem in učenjem odraslih prebivalcev. Leta 1969, v času študentskih gibanj v Evropi, so se prebudili tudi italijanski delavci. Zahtevali so pravico do dela, zdravja in tudi izobraževanja. Leta 1970 so ustanovili Inštitut delavcev, ki se je posvetil vprašanju izobraževanja zaposlenih. Leta 1973 pa so uvedli sloviti sistem, imenovan » 150 ur«. Zakon je določal, da so v skladu s pravico do izobraževanja zaposleni upravičeni do 150 plačanih ur izobraževanja med delovnim časom. Načeloma nihče ne more vplivati na to, kakšne študijske vsebine delavec izbere. Število ur in način njihove uporabe pa sta deloma vendarle $\mathrm{v}$ rokah organov v podjetju. Delavec jih lahko uporabi za šolanje, udeležbo na seminarjih za poklicno usposabljanje. Podoben zakon imajo tudi v Franciji. Tam se lahko vsakih sedem let delavec leto dni izobražuje in mnogi na koncu takšnega izobraževanja zamenjajo poklic. Izobraževanje pa ni nujno povezano z njihovim delom, lahko je prilagojeno tudi njihovim željam, dejavnostim v prostem času, ki lahko z izobraževanjem prerastejo v poklic. Za takšno izobraževanje plačujejo davke vsa podjetja, ki zaposlujejo več kot deset delavcev.

V Italiji se lahko delavci v skladu s tem zakonom šolajo 12 ur na teden, in sicer v oblikah, ki začnejo delovati, če je vpisanih vsaj dvajset slušateljev. Čeprav je obstoj zakona spodbuden, ugotavljajo, da od razpoložljivih sredstev zares uporabijo le četrtino. Resne analize vzrokov še niso naredili. Domnevamo pa lahko, da je razlog v izobrazbeni ravni delavcev. Ker je ta dokaj nizka, delavci v izobraževanju ne vidijo rešitve. Animacija delavcev za izobraževanje ni dovolj dobro razvita. Tudi delavci, ki se odločijo za izobraževanje, namreč tvegajo, da jih po končanem izobraževanju ne bodo več potrebovali. Težave so tudi z izobraževalci, ki so večinoma že tako preobremenjeni učitelji srednjih šol, ne posebej izobraženi za delo z odraslimi. Tako značilnosti začetnega izobraževanja, kot so obveznost, pouk, avtoritarnost, itd., pogosto nehote prenesejo $\mathrm{v}$ izobraževanje delavcev, ki potrebujejo bolj dialoški način učenja. Zato se je zelo razširilo izobraževanje izobraževalcev. Organizatorji takšnega izobraževanja so osnovne in srednje šole, $v$ zadnjem času pa tudi univerza. Univerza pripravlja tečaje, povezane $\mathrm{z}$ delom in dejavnostjo udeležencev. Takšno izobraževanje prirejajo tudi nevladne organizacije, kot so ljudske univerze, poulične univerze, zasebne izobraževalne organizacije, sindikati itd. Izobraževanje finančno podpirata država in lokalna oblast.* Financiranje pa zagotavljajo tudi skladi, na primer sklada Fiat ali Olivetti, ki razpisujejo štipendije, podpirajo pa tudi učitelje ali razvoj kulturnih akcij. Država pa zagotavlja učiteljem pedagoško andragoško izobraževanje. Kljub pomanjkljivostim je zakon »150 ur« vendarle vplival na zavest o potrebnosti izobraževanja odraslih in povzročil tudi povečanje naložb v izobraževanje odraslih.

$\mathrm{V}$ okviru tega zakona razmišljajo tudi o izobraževanju starejših delavcev. To naj bi bili delavci, stari več kot 45 let, čeprav so v drugih

Izobraževanje odraslih Italijani pojmujejo kot instrument za doseganje družbene pravičnosti. Prepričani so, da sta usposabljanje in izobraževanje odraslih del reforme socialne države. V zvezi s tem je nastalo veliko izobraževalnih projektov na lokalni ravni. 
državah delavci z vidika tržnega gospodarstva v kategoriji starejši že pri 40 letih. Vdor svetovne »kulture trošenja «, ki jo narekujejo veli$\mathrm{ka}$ večnacionalna podjetja, sili v premislek o potrebnosti splošnega izobraževanja in vzgoje za bolj prosvetljeno porabo. Takšno, ki ustreza dejanskim potrebam posameznika ter skupnosti in zagotavlja trajnostni razvoj.

Da bi se izobraževanje odraslih razvilo $\mathrm{v}$ trden sistem, je treba poskrbeti za to, da se zabrišejo ločnice med šolo, zaposlitvijo in dejavnim življenjem. Sistem, ki bi se posvetil na primer samo izobraževanju za delo, ne bi bil celosten in ne bi imel pravega vpliva na ljudi ter skupnost. Tako imajo $\mathrm{v}$ izobraževalnih programih najraje module, ki ustrezajo posameznim vidikom dela in življenja.

Prepričani so, da je izobraževanje odraslih neločljivo povezano z lokalnim razvojem. Na Madžarskem pa, kjer gre še zmeraj za družbo, ki deluje po načelih in zmožnostih industrijske družbe (zanjo so značilne ostra delitev dela, področij itd.), pa tega nekako ne morejo razumeti. $\mathrm{V}$ njihovih očeh je vse jasno ločeno. Izobraževanje odraslih je pravzaprav ločeno od kulture in lokalnega razvoja. V Sloveniji je v posameznih okoljih razvoj izobraževanja odraslih za lokalni razvoj vendarle pripomogel $\mathrm{k}$ zavesti, da je razvoj mogoč le $\mathrm{z}$ ljudmi. V sedanjem času, ko specializiranost industrijskega obdobja več ne zadošča, si morajo ljudje pridobiti čim več splošne izobraženosti in kulture, če se hočejo odzivati na nenehni razvoj in se razvijati sočasno $z$ družino, podjetjem, krajem, državo.

Izobraževanje odraslih, ki poteka v italijanskih osnovnih in srednjih šolah, je bilo doslej izrazito poklicne narave. To je privedlo do zahteve po reformi sistema. Izobraževanje odraslih je v tej reformi dobilo drugačen položaj: iz šolskega izobraževanja se je prelevilo v vseživljenjsko izobraževanje. To pomeni, da se tudi tisto izobraževanje, ki poteka v šolah, vključuje v shemo vseživljenjskega izobraževanja. Vse- življenjsko izobraževanje pa je, če naj bo zares takšno, povezano z delom in življenjem. Spreminja se miselnost, da se človek najprej uči in se šele nato, kot zaporniki, vključi v življenje. Da bi šole zadostile tem zahtevam, so se začele povezovati s partnerji oziroma območnimi skupnostmi za zaposlovanje in drugimi ustanovami. Uvedle so sisteme vrednostnih enot ali »kreditne sisteme«. Povezale pa so se vse šole, od osnovnih do višjih šol in univerze.

Temu je sledila ustanovitev teritorialnih centrov za izobraževanje odraslih. Ti se ukvarjajo $\mathrm{z}$ analizo potreb po izobraževanju in usklajevanjem razdrobljene izobraževalne ponudbe. Zakon namreč določa usklajeno delovanje različnih lokalnih nosilcev izobraževanja. Naloga teh centrov je tudi $v$ tem, da prepoznavajo tiste, ki potrebujejo izobraževanje, jim svetujejo in jih usmerjajo. Njihovo vloga je še posebej pomembna pri začetnem opismenjevanju in zagotavljanju funkcionalne pismenosti odraslih. Opisme-

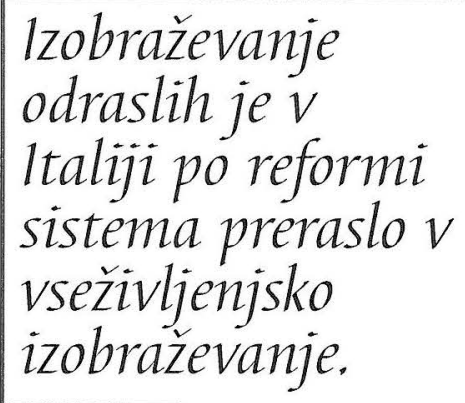
njevanje mora biti takšno, da omogoča tudi vrnitev $\mathrm{v}$ šole. To je pomembno zlasti za družbeno izločene priseljence.

Ta reforma ni bila preprosta, kajti odpreti šolo, ki je tog sistem, navzven je težka naloga. Težava šol je namreč $v$ tem, da so obrnjene same vase in da ne uvidijo stvarnosti. Tako se danes mladi v Rimu za frizerja usposabljajo v 2.500 tečajih. Že danes je mogoče napovedati, da to pomeni 250.000 brezposelnih. Tudi v Sloveniji poteka izobraževanje za šivilje, čeprav se pripravljamo na vstop $v$ Evropsko unijo, kjer tekstilna industrija nazaduje in pušča za seboj opustela mesta, ljudje so brezposelni in se že več let preusposabljajo.

Posebno težavo pomenijo ljudje, ki do 35. leta starosti še niso bili zaposleni. Ti so izgubili navdušenje za izobraževanje, pa tudi njihove izkušnje s šolanjem največkrat niso prijetne. 


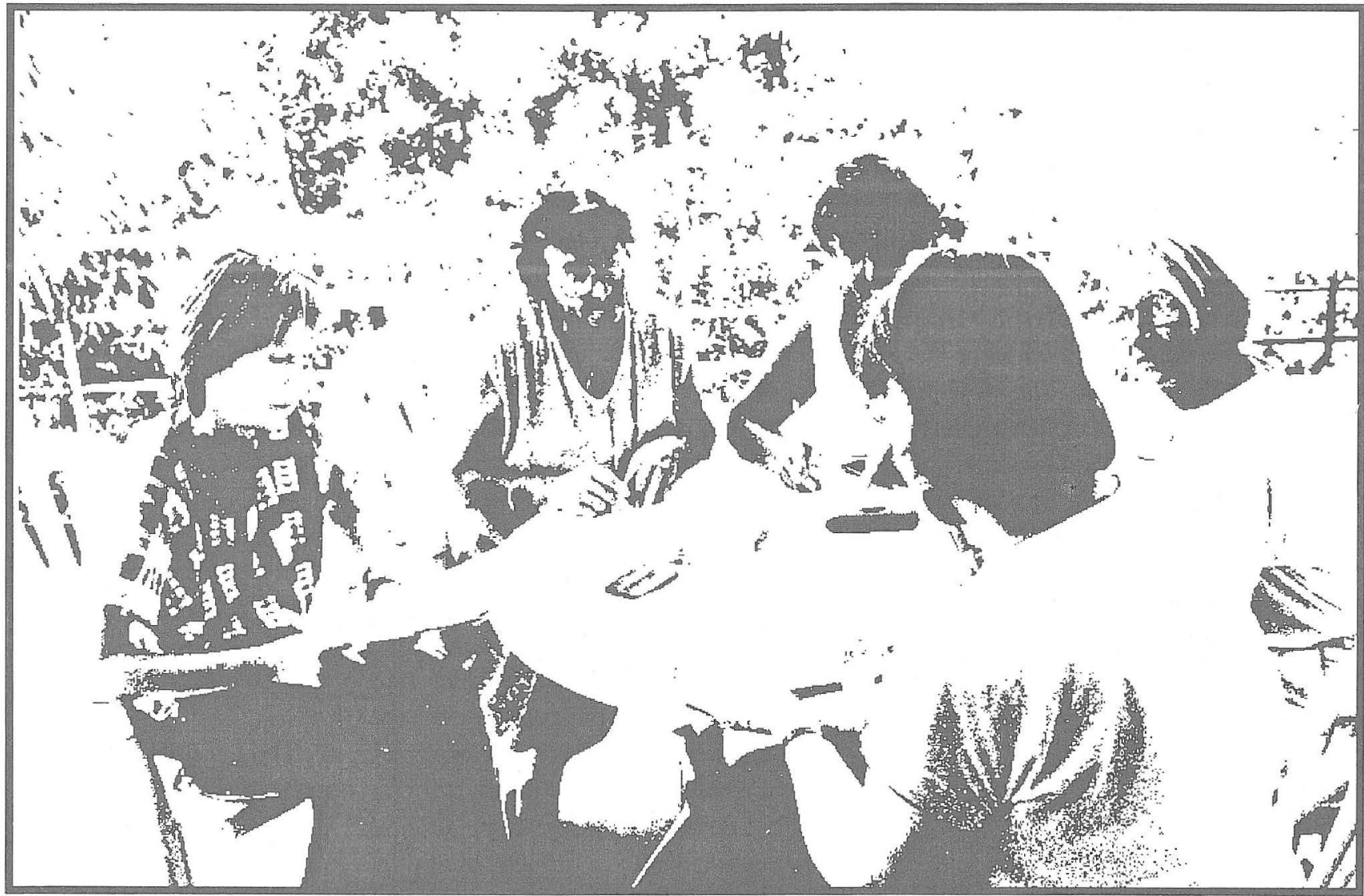

Kako jih pritegniti, se sprašujejo Italijani. V akcijah za lokalni razvoj ali, kot jih mi imenujemo, v lokalnih zaposlitvenih pobudah se ti ljudje učijo dela, socialne povezanosti in še marsičesa drugega. Akcije vodijo v ustvarjanje novih delovnih mest. Še več, v Italiji so prepričani, da je zdaj konec lokalnega razvoja na papirju in zahtevajo »konstrukcijo soglasja med ljudmi in partnerji $\ll$. V ta na namen je treba za sodelovanje in doseganje soglasja motivirati in izobraževati vse partnerje. Tako je nastal nov instrument. tj. regionalna platforma za spodbujanje izobraževanja odraslih. Izobraževanje je bistvena sestavina razvoja in vključevanja izločenih v družbi. Sistem izobraževanja odraslih je del aktivne politike zaposlovanja, ki ga poskušajo uvajati:

- z ugotavljanjem stanja na posameznem območju oziroma opisom možnosti,
- s pogovori s kadrovskimi direktorji v podjetjih,

- z akcijami usmerjanja mladih,

- z namenskim usposabljanjem,

- s finančno podporo ustvarjenim delovnim mestom.

Gre za povezano uporabo teh instrumentov. Namen izobraževanja odraslih je predvsem razvoj lokalnih skupnosti.

Lahko rečemo, da je današnji sistem izobraževanja odraslih v Italiji bliže dejanskim potrebam, kot je bil nekoč. Odziva se na potrebe posameznikov in lokalnega okolja. Podrobnejše preučevanje sicer pokaže, da ni dovolj posluha za razlike med industrijskim severom in bolj zaostalim jugom. Prav te so v Italiji narekovale večjo vpletenost izobraževanja odraslih $\mathrm{v}$ lokalni in regionalni razvoj oziro- 
ma večjo zavest o njegovi povezanosti $\mathrm{z}$ razvojem kraja.

\section{SISTEM IZOBRAŽEVANJA NA IRSKEM JE EDEN OD TEMELJEV GOSPODARSKEGA RAZCVETA}

Najočitnejša posebnost so mladi. Kar 40 odstotkov Ircev je starih manj kot dvajset let. Nezaposlenosti skorajda ni. Še več, kažejo se velike potrebe in na Irskem vsako leto potrebujejo 19.000 novih delovnih mest. Gospodarstvo cveti. Pravijo, da zaradi kulturne povezanosti z ZDA, izvoza (80 odstotkov) v države Evropske unije, ugodnih možnostih za tuje investitorje, števila mladih ljudi in tudi razvitosti ter vloge izobraževanja odraslih.

$\mathrm{Na}$ Irskem deluje odbor za izobraževanje odraslih, ki je namenjen različnim ravnem izobraževanja odraslih. Poznajo višje šole, tečaje za maturo, imajo razvito aktivno politiko zaposlovanja, močno zasebno izobraževalno ponudbo in skupnostno izobraževanje. Njihova značilnost so tudi odbori, ki jih ustanavljajo po potrebi in ki skrbijo za vprašanja funkcionalne pismenosti. $\mathrm{V}$ ta namen uporabljajo denar za preprečevanje tega pojava, pa tudi sredstva, namenjena razvoju skupnostnega izobraževanja.

Visokošolsko izobraževanje je namenjeno tudi odraslim in spodbuja njihovo vključevanje. Odrasli si lahko pridobijo diplome višjih šol, lahko se udeležujejo tečajev, na katerih se pripravljajo na študij.

Obstajajo tudi aktivni programi za trg dela in za mlade ljudi, ki jih večinoma podpira Evropska unija (80 odstotkov). V poklicno izobraževanje odraslih se vključujejo tisti, ki so stari več kot 23 let in vsaj leto dni brezposelni. Drugi programi zajemajo mlade med 16. in 22. letom.

Skupnostni centri pripravljajo projekte skupnostnega zaposlovanja. Gre za projekte, ki so značilni za tako imenovano socialno ali vza- jemnostno gospodarstvo in povezani z življenjem skupnosti. Namenjeni so zaščiti okolja, kulturi, storitvam za posameznika itd. V teh projektih je predvideno tudi izobraževanje odraslih, in sicer 20 ur na mesec.

Pripravljajo tudi projekte usposabljanja za razvoj splošnih možnosti, potrebnih za ravnanje $\mathrm{z}$ računalniki, poslovanje itd. Namenjeni so predvsem brezposelnim prejemnikom socialne podpore.

Velika je tudi izobraževalna ponudba zasebnih izobraževalnih kolidžev na področju managementa, računalništva. Gre za pridobitne programe, ki so precej dragi.

Najbolj dinamično izobraževalno področje na Irskem je skupnostno izobraževanje, ki ga vodijo lokalne skupnosti. Ta oblika izobraževanja je namenjena vključevanju izločenih $\mathrm{v}$ družbi in je brezplačna ali zelo poceni.

Doslej so bili prepričani, da je izobraževanje odraslih »pepelka šolskega izobraževanja

Bela knjiga, ki so jo sprejeli avgusta 2000, pa je to prepričanje spremenila. Pred volitvami leta 1997 so namreč izobraževalci odraslih zahtevali, naj politične stranke posvetijo pozornost skupnostnemu izo-

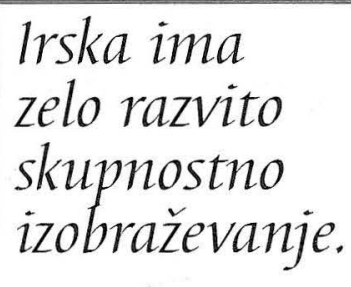
braževanju in naj se ustanovi ministrstvo za izobraževanje odraslih. Zahtevali so letno podvojitev proračuna izobraževanja odraslih, programe za odpravljanje in preprečevanje funkcionalne nepismenosti.

Njihova politična prizadevanja se kažejo $\mathrm{v}$ tem, da je bilo ustanovljeno ministrstvo za izobraževanje odraslih, zagotovljena podpora izobraževalnim pobudam, da so ustanovili službe za usmerjanje odraslih in svetovanje odraslim. V zvezi s tem: 1. se je razvila nacionalna politika $\mathrm{v}$ povezavi $\mathrm{s}$ funkcionalno nepismenostjo; 2 . je nacionalna televizija pripravila serijo oddaj o pismenosti; 3 . so se na lokalnem radiu razvile pilotne strukture za funkcionalno pismenost, ki ustrezajo potre- 
bam ljudi, in ne potrebam sheme za preprečevanje nepismenosti; 4. se pripravlja analiza ovir za vključevanje v izobraževanje odraslih; 5. je nastal projekt Pismenost na delovnem mestu, ki na delovnem mestu zagotavlja dostop do računalnikov, in sicer 24 ur na dan, sedem dni v tednu; med izmenami je 20 minut navzoč »učitelj pismenosti« za pomoč za delo na računalnikih.

Na Irskem je vse več možnosti za izredni študij. Vključujejo se odrasli, ki jim ni uspelo končati višješolskega študija. Sistem je krediten. Pomoč je zagotovljena na prehodu iz srednje šole na univerzo. Pri tem sodeluje 6.000 zaposlenih, ki se posebej ukvarjajo z ljudmi v stiski. Tistim, ki so revni, ni treba plačati šolnine. Šole ustvarjeni dobiček porabijo za nadaljnje investicije $v$ izobră̌evanje odraslih.

Nacionalni svet za financiranje izobraževanja sestavljajo predstavniki lokalnih skupnosti, slušatelji, ponudniki izobraževanja, sindikati, kmetje, delodajalci.

$\mathrm{V}$ kratkem bodo ustanovili forum udeležencev in nacionalni organ za izobraževanje odraslih. Ukvarjala se bosta z razvojem politike izobraževanja odraslih, spodbujala usklajevanje tega področja, povezovanje $z$ uporabniki, raziskovanje in določanje standardov kakovosti, usposabljanje učiteljev in mednarodno povezovanje.

Da je učinkovitost sprejetih ukrepov odvisna od motiviranosti, ne poudarjajo samo v Italiji, marveč tudi na Irskem. Posamezniki bi morali zaupati v svoje zmožnosti, tudi izobraževalne. Tako izobraževalne in druge ustanove veliko razmišljajo o animaciji ljudi za izobraževanje. Izobraževanje naj bi, tudi iz motivacijskih razlogov, vodilo tudi $\mathrm{v}$ zaposlovanje brezposelnih. To je najlaže doseči s skupnostnim izobraževanjem, ki zajema izobraževanje žensk, izobraževanje za pridobivanje samozavesti, osebni razvoj in upravljanje lokalne skupnosti. Z izobraževanjem prostovoljnih skupin se ukvarja tudi AONTAS, nacionalno združenje za izobraževanje odraslih.
Kažejo se potrebe povezovanja skupnostnega izobraževanja $\mathrm{z}$ institucionaliziranim izobraževanjem odraslih. Institucionalizirano izobraževanje namreč črpa tudi iz raziskav o tem, kako se učijo ljudje v lokalni skupnosti. Tako je spodbudnejše za ljudi. Skupnostno izobraževanje je na Irskem navsezadnje spoštovano tudi zato, ker je dolgo prosvetljevalo ljudi, zakaj in kako je treba zaustaviti vojno, pa tudi zato, ker jih je naučilo prevzeti odgovornost za njihov kraj.

Priznavanje $\mathrm{z}$ delom in življenjem pridobljenih zmožnosti je značilno predvsem za področje tehničnih spretnosti.

$\mathrm{Na}$ Irskem so prepričani, da kljub vsem uspehom, ki jih dosegajo, družbena struktura zaostaja za razvojem ljudi. Dejavno državljanstvo, zlasti v zvezi z delom z mladimi, športom, urejanjem cestne signalizacije itd., je merljivo. Vendar je veliko nerešenih vprašanj, na primer, ali ljudje zares vodijo sami skupnostne centre. Kakšne se v resnici te strukture? Koliko ustrezajo namenu svoje ustanovitve? Na tem področju čakajo izobraževanje odraslih še številne naloge.

\section{V ŠVICI PORABIJO ZA IZOBRAŽEVANJE ODRASLIH VEČ SREDSTEV KOT ZA VSE DRUGE OBLIKE IZOBRAŽEVANIA}

Tradicionalno uspešna industrija $v$ Švici nazaduje, na primer tekstilna industrija, proizvodnja bele tehnike, gradbena industrija, krepi pa se terciarni sektor. Leta 1990 je bilo v terciarnem sektorju zaposlenih že 67,2 odstotka ljudi. Nastajajo novi poklici, za katere pa ljudje niso dovolj usposobljeni. Tako se povečuje izobraževanje, ki omogoča tako imenovane ključne kvalifikacije, pravzaprav splošno usposobljenost, ki je bolj povezana $\mathrm{z}$ osebnostno in kulturno rastjo posameznika in ki ne omogoča le poklicnih spretnosti, marveč spretnosti, uporabljive v mnogih poklicih. 
Lahko bi rekli, da Švica ne zaostaja za razvojem, saj ne uporablja več konceptov, značilnih za industrijsko družbo: poklicno izobraževanje, pridobivanje natančno določenih spretnosti. Odprtost terciarnega sektorja zahteva od ljudi splošne zmožnosti.

Eden značilnih pojavov izobraževanja odraslih v Švici so tako imenovane klubske šole, ki so nastale pod vplivom japonskega izobraževanja oziroma tistega izobraževanja, ki ga omogočajo velike japonske trgovske verige kot pomembni ponudniki in sponzorji. Klubske šole so nastale na pobudo velike trgovske mreže MIGRO, namenjene revnejšim slojem. MIGRO namenja kulturnim akcijam odstotek svojega dohodka, tj. približno 22 milijard frankov, 110 milijard pa nameni klubskim šolam.

Interno izobraževanje ponujajo zunanjim udeležencem tudi Swiss Air, velike banke, še posebej tečaje računalništva. Med vsemi programi so najuspešnejši tisti, ki imajo 20-30 ur. Več zaposleni Švicarji namreč ne zmorejo. Izobražujejo se predvsem zato: 1 . da bi si izboljšali družbeni in materialni položaj; 2 . da ne bi zaostajali za razvojem; 3 . zaradi ve-

Śvica ima 26 kantonov, torej tudi 26 parlamentov in 26 sistemov izobraževanja odraslih. Sistem neposredne demokracije se torej kaže tudi $\mathrm{v}$ zvezi $\mathrm{z}$ izobraževanjem. 31 odstotkov izobraževanja odraslih zagotavljajo podjetja, 50 odstotkov zasebni ponudniki in 19 odstotkov odprti sektor. Obseg izobraževanja odraslih je velik. V züriškem kantonu je tako več kot 900 izobraževalnih ustanov in za področje izobraževanja odraslih je značilen svoboden trg. 42 odstotkov odraslih se udeleži vsaj enega tečaja na leto. Tako ni čudno, da obstajajo nekakšne borze ponudbe in "prodaja« izobraževanja odraslih, zato izbira za udeležence izobraževanja ni lahka. Pri tem jim je v pomoč SVEB - švicarska zveza za izobraževanje odraslih. selja; 4. da bi bolje razumeli svoje okolje; 5 . da bi zadržali delovno mesto. Večina izobraževanja je rezidenčnega. 52 odstotkov ljudi se izobražuje za poklic, 48 odstotkov pa se jih udeležuje splošnega izobraževanja.

Socialna varnost in izobraževanje odraslih sta najpomembnejši postavki v švicarskem proračunu, daleč nad drugimi področji, Namenjen jima je precej večji proračunski delež kot za zdravje. Za izobraževanje odraslih pa porabijo več sredstev kot za vse druge oblike izobraževanja.

V Švici sta naj-
večja proračunska
porabnika social-
na varnost in
izobraževanje
odraslih.
Odrasli se zavedajo pomena izobraževanja odraslih, tako da bi to področje preživelo tudi brez pomoči države in Evropske unije.

\section{V ŠPANIJI JE ZAKON O IZOBRAŽEVANJU ODRASLIH KODIFICIRAL VOLJO LJUDI IN USTANOV}

Razvoj izobraževanja odraslih v Španiji zaznamuje nekaj temeljnih dogodkov. Zavedajo se namreč, da 1 . iz industrijske prehajajo $v$ informacijsko družbo. Tam, kjer so še včeraj stala velika industrijska podjetja s 3.000 delavci, so zdaj majhna podjetja s tristo delavci, ki naredijo dosti več kot nekdanjih 3.000 . So pa seveda delavci dosti bolj izobraženi. $\mathrm{V}$ baskovskem Bilbau so na mestu, kjer so bili še včeraj kupi odpadnega rjavečega železa, simbola industrijske družbe, zgradili muzej Guggenheim. Mnogi so nasprotovali, kajti novo poslopje, ki spominja na sidneysko opero, je zahtevalo mnogo truda. Kmalu po postavitvi muzeja pa se je začela spreminjati podoba celotnega mesta. O kupih rjavečega železa ni več sledu, v novi muzej pa prihajajo trume turistov. Začel se je razvijati nov gospodarski sektor, veliko primernejši za informacijsko družbo, ki prinaša nove potrebe in načine 


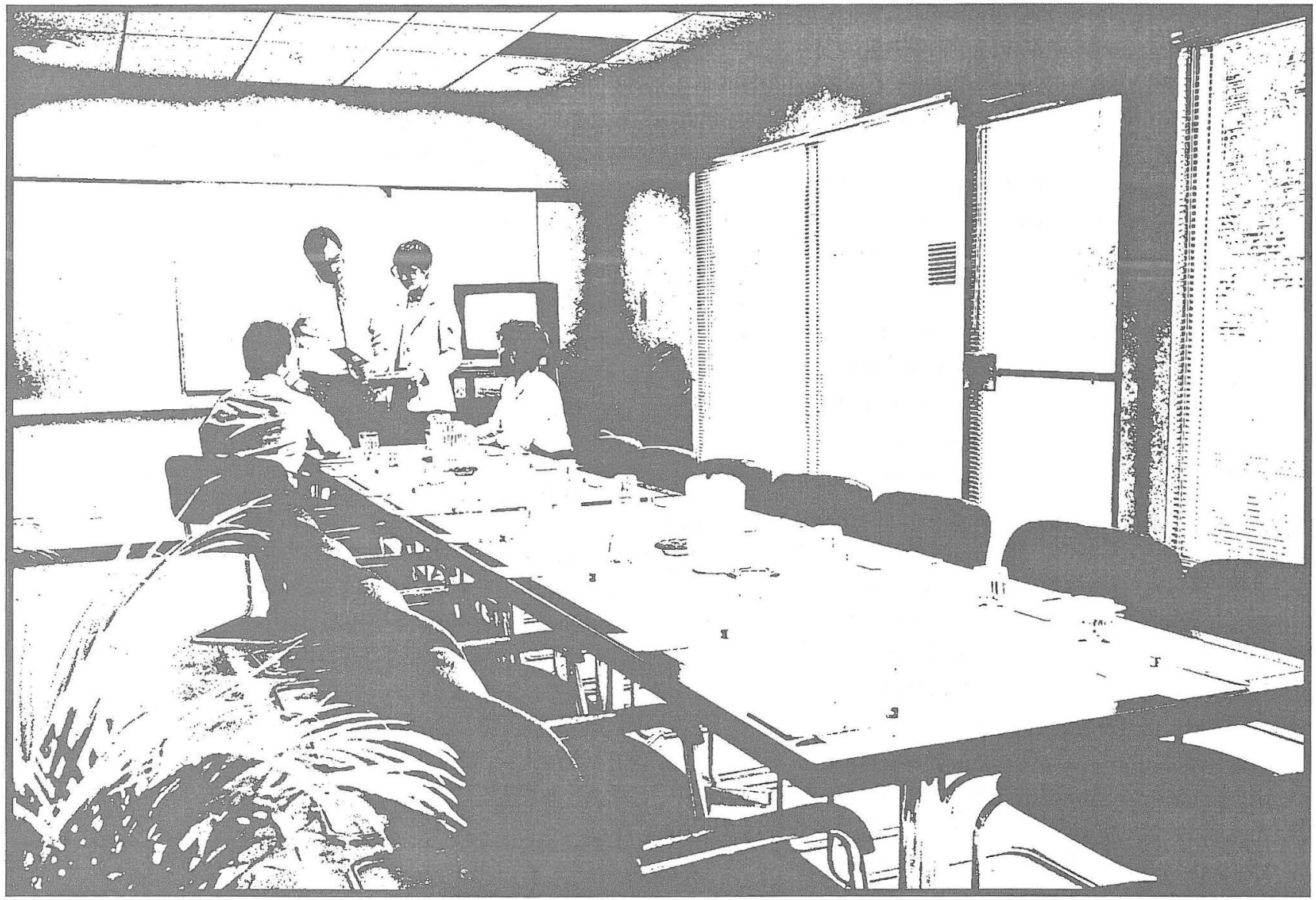

učenja. 2. Po smrti diktatorja Franca so se Španci odločili za demokracijo, spoznali so namreč, da si smernice za razvoj in meje postavljajo sami in da so odgovorni sami. 3. Priključili so se Evropski uniji, kar je v dobrem in slabem preusmerilo njihov razvoj in se 4 . iz homogene družbe razvili v multikulturno družbo.

Velik pomen pripisujejo zakonodaji o izobraževanju odraslih. Ker izobraževanje odraslih ni le domena izobraževalcev in njihovih ustanov ter državne politike, so zakone sprejemali postopoma. Vzeli so si čas za temeljito javno razpravo, v kateri so sodelovali odrasli udeleženci izobraževanja, izobraževalci, sindikati, podjetja in drugi partnerji. Razprava je nakazala različne vidike, ki so jih zajeli v širok, fleksibilen zakon. Menijo, da takšen zakon ustreza temeljni naravi izobraževanja odraslih, tj. odzivnosti na kulturne, ekonomske, družbene, politične potrebe in spremembe. Vsekakor pa niso naredili napake, saj zakona niso sprejeli brez družbene razprave. V tem se kaže demokratična usmerjenost današnje Španije. Zakon je nastajal $v$ posameznih avtonomnih pokrajinah. Tam, kjer so se odprtemu zakonu odpovedali, na primer v Andaluziji, izobraževanje odraslih usiha, drugje pa se razvija.

Sicer pa je izobraževanje odraslih doživelo številne spremembe. Od predvsem nadomestnega, kompenzacijskega izobraževanja, ki je pomagalo nadomestiti $\mathrm{v}$ preteklosti nastale primanjkljaje, se je razvilo izobraževanje, ki napoveduje spremembe. Za to si prizadevamo tudi pri nas.

Nadomestno izobraževanje $v$ prihodnost pro- 
jicira preteklost, Izobraževanje odraslih je tako znamenje nezadostne razvitosti družbe, in to je treba spremeniti. Vendar nekateri menijo, da izobraževanje odraslih pravzaprav ni potrebno, saj bodo s šolsko reformo šole »pokrile« vse potrebe, in da je primeren čas za učenje mladost, le redko odraslo obdobje. Koncept takšnega izobraževanja odraslih posnema šolski koncept.

Nadomestno izobraževanje je potrebno, kajti še do nedavnega je bilo obvezno šolanje do 14. leta starosti, nedavno se je podalǰsalo do 16. leta starosti, tisti, ki želijo, pa lahko ostanejo v šolah do 18. leta, saj jim to dopušča država.

Zakon iz leta 1990 predvideva, da splošno srednje izobraževanje vodi na univerzo, poklicno pa lahko odloži ljudi v slepi ulici, ki ne vodi naprej, na univerzo namreč. To je nedvomno neugoden in zastarel zakon. Po letu 1990 so imeli torej možnost nadaljevanja študija tisti, ki so se šolali $v$ gimnazijah in dobrih poklicnih šolah. Za tiste v programih, ki ustrezajo našim $3+2$, pa ni bilo poti, ki bi vodila naprej. Tudi to je oblika družbenega darvinizma.

Kmalu se je izkazalo, da bo Španija močno zaostala za drugimi, če bo ohranila takšen izobraževalni sistem. Zato ga zdaj reformirajo in skušajo zgraditi mostove med srednjim izobraževanjem, ki zapre pot na univerzo. K temu spoznanju je privedlo tudi to, da se je število posameznikov z nedokončano osnovno šolo povečalo, saj se je osnovno šolanje podaljšalo. Leta 1981 ni imelo končane

Nov španski zakon o izobraževanju ne pojmuje izobraževanja kot nasledek preteklosti, temveč kot nasledek zdajšnjega razvo$j a$ in ključno sestavino življenja $v$ informacijski družbi. Izobraževalna reforma je povečala število odraslih, ki se izobražujejo, v izobraževanje odraslih pa se vse bolj vključujejo tudi univerze. osnovne šole 39 odstotkov aktivnega prebivalstva, danes, ko več ljudi potrebuje temeljno izobraževanje, pa jih je 75 odstotkov.

Odrasli so se združili v zvezo uporabnikov, ki jo mora vlada upoštevati pri svojih odločitvah. Ustanovili so tudi združenje za raziskovanje na področju izobraževanja odraslih.

Od izobraževanja, usmerjenega v stroko, so prešli k izobraževanju, ki se osredotoča na udeležence. Od birokratskih šol želijo preiti k učeči se družbi. Izobraževanje odraslih je danes v ospredju družbenih sprememb in sprememb v šolah.

Opuščajo tradicionalne koncepte učenja in vse bolj verjamejo v dialoško učenje. Učenje, ki odpira enake možnosti za vse, ki upošteva mnenje drugega in njegov svetovni nazor. Ko govorijo o spremembah, in teh je bilo pri njih veliko, menijo, da se vse spreminja, poleg šole. Zaradi številnih sprememb so se znašli tudi $v$ različnih razvojnih fazah izobraževanja odraslih. V prvi fazi se je pri njih uveljavil »družbeni darvinizem«. Izobraževali bomo tiste, ki bodo lahko preživeli na trgu delovne sile, drugim bomo le pomagali. Podobno miselnost velja tudi pri nas, sicer ne bi imeli tolikšne ponudbe izobraževanja za managerje in druge že izobražene, in tako malo možnosti za 60 ali 70 odstotkov funkcionalno nepismenih, ki so morebiti trajno nezaposljivi. Nekateri bodo torej vstopili $\mathrm{v}$ informacijsko družbo, drugi pa ne. Naslednja faza, v katero $v$ Španiji počasi vstopajo, pa je prav zagotoviti vstop $\mathrm{v}$ informacijsko družbo za vse. $\gg \mathrm{Za}$ vse« pomeni tudi milijon španskih Romov, ki prav tako kot na Madžarskem ne smejo biti zanemarljiv delež prebivalstva.

\section{Dušana Findeisen}

\footnotetext{
*Poulična univerza ali Universita di strada izhaja iz izobraževanja starejših in njihovih potreb, sedaj pa se ukvarja z izobraževanjem družbeno izločenih.
} 